\title{
Local Economic Development Strategies and Challenges: A Comparative Empirical Evidence from \\ Ghana's Local Governance System
}

\author{
Akpeko Agbevade \\ Department of Political Science, University of Ghana, Legon, \\ P.O. Box LG 61, Legon Accra, Ghana \\ E-mail: aagbevade@gmail.com \\ TEL: $+233(0) 243340551$
}

Received: Sep. 21, 2018 Accepted: Oct. 12, 2018 Online published: Nov. 12, 2018

doi:10.5296/jpag.v8i4.13894ＵRL: https://doi.org/10.5296/jpag.v8i4.13894

\begin{abstract}
Local level economic development has eluded Ghana since independence. This was because most policies were centralized. As a result, focus was shifted to local economic development. This article comparatively examined the local economic development strategies implemented in three of Ghana's Metropolitan, Municipal and District Assemblies. Using the mixed method and multiple case study approaches of research, the study sampled a total of 533 respondents across the three Metropolitan, Municipal and District Assemblies and analyzed data using the Statistical Package for the Social Sciences. The study gleaned that the Metropolitan, Municipal and District Assemblies implemented similar local economic development strategies which could be categorized into contemporary local economic development and traditional local economic development approaches. Challenges such as inadequate finance, land tenure system, lack of modern equipment among others were identified. The provision of a central pool for financing local economic development, harmonization of locality development policies, de-politicization of local economic development policies, the adoption of change management strategies in Ghana's local governance system, effective land tenure system are recommended for the success of local economic development in Ghana.
\end{abstract}

Keywords: local economic development, local economic development strategies, implementation, metropolitan, municipal and district assemblies 


\section{Introduction}

Ghana since independence in 1957, have implemented both statist and market oriented strategies to address the development deficit at the local level. Notable among the policies were; the Seven Year Development Plan, 1963-1970, the Economic Recovery Programme (ERP), 1983 which resulted in the Structural Adjustment Programme (SAP),1987, the Ghana Regional Appropriate Technology Industrial Service (GRATIS) project, 1987, Vision 2020, 1996-2020, the Millennium Development Goals (MDGs), 2000, President's Special Initiatives (PSIs) on garment and textiles and agriculture (Cassava and oil palm), 2001-2007, Ghana Poverty Reduction Strategy (GPRS 1), 2003-2005, Growth and Poverty Reduction Strategy (GPRS 2), 2006-2009, the Ghana Shared Growth and Development Agenda (GSGDA I), 2010-2013, GSGDA II, 2014-2017, One District One Factory (1D1F), 2017 among others (Ayee, 2007:15; Ninsin, 2007:98; Amoako-Tuffour and Armah, 2008:4-7; Mensah et.al. 2013, Mensah et.al. 2017). These policies could not achieve the desired objectives because of centralization, implementation bottlenecks and lack of institutional coordination (Wunsch, 2014:5; Tsikata, 2007: 56; World Bank, 1989:60).

In view of this, decentralization was seen as the panacea to grassroots economic development, but it also failed to yield the needed result due to local governance units' (LGUs) excessive concentration on political, social and administrative development to the detriment of economic decentralization. These failures gave currency to the adoption of local economic development (LED) which is seen as a partnership between the government, local government units and other partners to utilize the available resources of a locality to create new employment opportunities, generate income, provide infrastructure and poverty reduction (Republic of Ghana, 2013, 2014).

Against this backdrop, the study comparatively examines the LED strategies and the challenges encountered in the implementation process using the Accra Metropolitan Assembly (AMA), Keta Municipal Assembly (KeMA) and Shai-Osudoku District Assembly (SODA) in Ghana as case studies.

The study is structured as follows: statement of the problem, objectives and research questions, literature review, profile of the study areas, methodology, findings and discussions, recommendations and conclusion.

\section{Statement of the Problem}

In the literature, LED as a bottom-up approach to development has largely been seen from the policy and institutional perspectives, adoption of strategies and the role of local government units, international organisations and medium scale enterprises as actors in LED in Ghana and the challenges. Much attention has not been given to the comparative study of the Metropolitan, Municipal and District Assemblies (MMDAs) LED implementation and no direct studies have been done on the AMA, KeMA and SODA. This study therefore fills this literature lacunae. 


\section{Objectives and Research Questions}

The objectives of the study are to comparatively discuss the LED strategies implemented in the AMA, KeMA and SODA as well as the challenges faced in the course of the implementation. To address these objectives, two research questions are posed;

1. What were the LED initiatives designed and implemented in the AMA, KeMA and SODA and what were the similarities and differences? and

2. What were the challenges encountered and how did they inhibit the LED implementation process?

\section{Literature Review}

In the developed countries, literature abounds on LED because of the commitment to deepen development. In the case of Sub Saharan Africa (SSA), however, there is limited literature because LED as an alternative approach to development is a recent phenomenon (Oduro-Ofori, 2016:18) and therefore less attention has been given to it in the local governance system. Most of the literature on LED in SSA have come from scholars and researchers in South Africa which is considered as the "laboratory" of LED in Africa (Rogerson and Rogerson, 2010). In Ghana, studies on LED have come from experts in local governance, public administration and rural and regional development.

The studies on LED have been on the origin, the strategies, actors, beneficent outcomes, and challenges as well as the nexus between LED and poverty reduction.

In terms of the origin, LED as an alternative approach to development was first implemented in the high-income countries of the north dating back to the 1960s (Rodriguez-Pose and Tijmstra, 2005:3). Social and economic challenges such as the failure of traditional top-down, slow economic growth and poverty, changes in the national and international economy, failed structural adjustment programmes, inability of states to intervene at the local level among others were identified as the reasons for the emergence of LED in the developed world, sub-Saharan Africa (SSA) and Ghana (Nel, 2001, Helmsing, 2003, Mensah et.al., 2013).

On the strategies, Capkova (2005), World Bank (2002), and Pieterse (2006), enumerated the provision of financial services, property related tools, marketing assistance, infrastructure development, technical and information assistance, organisational structure, training and development, provision of quality services and empowerment and regeneration of disadvantaged localities were some LED strategies implemented in the developed world. In contributing to the discussion on the LED strategies, the UN-HABITAT (2005) defined LED strategies as a process-oriented and non-prescriptive endeavours which incorporates three elements, namely:

(i) local values such as poverty reduction, basic needs, local jobs, integration of social and environmental values;

(ii) economic drivers which include value added resource utilization, local skills training, 
local income retention and regional cooperation; and

(iii) development which encompasses the role of structural change and the quality of development (UN-HABITAT, 2005:2).

The UN-HABITAT (2005:3) further argued that strategic planning is a necessity for the success of LED and consequently posed four strategic questions namely, "where are we now?; where do we want to go?; how are we going to get there?; and how do we know when we have arrived?".

In sub-Saharan Africa, Helmsing (2003) indicated that there are three new generations of LED initiatives, namely, community economic development, enterprise development and locality development and it is from these initiatives that LED programmes, interventions and strategies are derived. Strategies such as "One Village One Product" (OVOP) in Malawi, beekeeping in the West Nile in Uganda, tourism, Multi-Purpose Community Centres (MPCC) in South Africa among others have been examined in Africa (Rogerson and Rogerson, 2010; Enzama, 2008; Edoun and Jahed, 2009). Rogerson and Rogerson (2010) admonished that the effectiveness of the strategies hinges on their ability to create an enabling local business environment for small enterprise development. Rodriguez-Pose and Tijmstra (2005:17) stepped up the discussion on enabling environments by outlining three forms of enabling environments in local government units. These are: economic hardware, economic software and organisational capacity or "orgware". They stressed that the existence of these enabling environments resulted in the flourishing of LED.

In Ghana, strategies such as micro-credit provision, agro-processing, structural development, health and educational activities, upgrading the skills of artisans among others were identified by Ofei-Aboagye (2009), Mensah et. al. (2013) and Oduro-Ofori (2016). Oduro-Ofori (2016) elaborated on the strategies by arguing that LED has had minor impact due to the focus on "hardware" aspect of LED which was infrastructure instead of the "software" aspect which encompasses training programmes, access to credit and other intangible strategies that promote local economic development.

The role of actors such as local government and their institutions, community organisations, local producers and their associations have been extensively discussed in the literature (Yatta, 2015; Helmsing, 2003; Rogerson and Rogerson, 2010; Nyawo and Mubangizi, 2015; Oduro-Ofori, 2016).

Rogerson and Rogerson (2010) counselled that the actors, especially small towns and local government units should be strengthened to make them attractive and viable, and there should be engagement between local government units and entrepreneurs to ensure local sourcing and supplier linkages. The Republic of Namibia (2008) extended the studies on the actors by classifying the actors into two. These are public and social actors. The former comprises of state-owned enterprises, regional and traditional authorities and the latter consists of employers, non-governmental organisations (NGOs), community-based organisations (CBOs) and faith-based organisations. Oduro-Ofori (2016) and Nyawo and Mubangizi (2015) intimated that the absence of a clear policy guideline, lack of capacity, lack of cooperation 
between the local government units and other actors, politicization of the LED, and unnecessary bureaucracy negatively affected the actors in attaining LED objectives.

On the beneficent outcomes of LED, Helmsing, (2002, 2003) and the ILO, (2008) categorized the beneficent outcomes into social and economic. Socially, LED strategies empowered local societies and allowed for local dialogue and citizens' participation. It also made local institutions more transparent and accountable thereby strengthening the growth and development of civil society organisations (CSOs). Sustainable and decent employment, income generation and poverty reduction were some of the economic benefits (Masuku et.al. 2014; Ramukumba, 2012).

Challenges to the implementation of LED have also been identified. They include the lack of resources, inadequate qualified personnel, and human hindrances such as attitude to work, inadequate information systems, lack of systematic feedback, absence of clear-cut responsibility, absence of poverty reduction targets, politicization of LED initiatives and integration of the various LED partners. Khumalo (2015) and Nyawo and Mubangizi (2015) pointed out bottlenecks such as communication breakdown and lack of community participation in the LED process as challenges confronting LED in Africa. In Ghana, Akudugu (2013) for instance identified the top-down approach to implementation, poor formulation of national LED policy that was incapable of providing strategic direction for LED promotion, capacity constraints of the Metropolitan, Municipal and District Assemblies, and multiple and divergent actor rationalities as the bane of LED promotion..

From the above review, it can be inferred that no explicit comparative study has been done on the AMA, KeMA and SODA. This study will therefore contribute to the existing literature on LED by not only examining the LED strategies but also the challenges faced by the three Metropolitan, Municipal and District Assemblies comparatively.

\section{Profile of the Study Areas}

The Accra Metropolitan Assembly (AMA) was established in 1988. The AMA as it exists now was created in 2012 with Legislative Instrument (L.I.) 2034 following the carving out of the La Dadekotopon Municipal Assembly. It is the district capital, the regional capital for the Greater Accra Region as well as the national capital and the economic hub of Ghana.

The Keta Municipal Assembly (KeMA) with Keta as the municipal capital is one of the 25 administrative districts in the Volta Region. It was carved and created out of the former Anlo District by L.I. 1475 in 1989. It was upgraded to a municipal status in 2007 with L.I. 1868. It lies within Longitude $0.30^{\circ} \mathrm{E}$ and Latitudes $5.45^{\circ} \mathrm{N}$ and $6.005^{\circ} \mathrm{N}$. It is located to the east of the Volta estuary, about 160km from Accra.

The Shai-Osudoku District Assembly (SODA) is situated in the South-Eastern part of Ghana in the Greater Accra Region. The SODA was created following the L.I. 2137 in June, 2012 which mandated the splitting of the Dangbe West District Assembly into two districts namely, the Ningo Prampram and Shai- Osudoku District Assemblies.

Below are some statistics on the three Metropolitan, Municipal and District Assemblies 
Table 1. Key statistics of the Study Areas

\begin{tabular}{c|c|c|c}
\hline Name of MMDA/Areas of Comparison & AMA & KeMA & SODA \\
\hline Land size & $139,674 \mathrm{~km}^{2}$ & $753.1 \mathrm{~km}^{2}$ & $968,361 \mathrm{~km}^{2}$ \\
\hline Population & $1,665,086$ & 147,618 & 51,913 \\
\hline Level of Unemployment & $7.2 \%$, & $38 \%$ & $30.8 \%$ \\
\hline Level of poverty & $10.6 \%$, & $10 \%$ and $14.9 \%$ & $23.2 \%$ \\
\hline Average number per household & 3.7 & 3.8 & 4.4 \\
\hline
\end{tabular}

Source: Compiled by the Author from various publications of the Ghana Statistical Service

\section{Methodology of the Study}

The study adopted a mixed method approach research combined with multiple case study. Quantitative data was collected through the use of questionnaire whilst face to face interview was used to collect qualitative data. Both primary and secondary sources of data were used for the study. Data for the study was collected between April, 2017 and March, 2018 using different sampling techniques due to the multiple populations. The following officers were interviewed: Planning Officers and Directors of the Business Advisory Centres. A total of 533 LED beneficiaries was drawn from the AMA, KeMA and SODA with the break down as follows: 178, 178 and 177 respectively as the sample size (Table 2). The formula used in calculating the sample size was:

$$
\frac{N}{1+N\left(e^{2}\right)}
$$

Where $\mathrm{N}$ refers to the population of the Metropolitan, Municipal and District Assembly.

$\mathrm{e}^{2}$ refers to the margin of error which was $0.075^{2}$

Table 2. Sample size of the citizens of the MMDAS

\begin{tabular}{l|l|l|l}
\hline NAME OF MMDA & SAMPLE SIZE & MALE & FEMALE \\
\hline AMA & 178 & 86 & 92 \\
\hline KeMA & 178 & 83 & 95 \\
\hline SODA & 177 & 86 & 91 \\
\hline & 533 & 255 & 278 \\
\hline
\end{tabular}

NB: The gender breakdown was done using the population ratio of male to female

The data was analyzed using the Statistical Package for the Social Sciences. Local government units were used as the unit of analysis because it allowed for the identification of the unique factors that either promoted or hindered the implementation of LED in the three Assemblies.

\section{Findings and Discussions of the Study}

This section of the article is categorized into two sub-sections, namely; the LED strategies and the challenges

\subsection{The LED Strategies}

The Metropolitan, Municipal and District Assemblies adopted different strategies in the 
implementation of LED. The AMA implemented both Public Private Partnerships (PPPs) and business development programmes as its LED intervention, the KeMA implemented both traditional handicraft and non-traditional LED initiatives and the SODA implemented software and hardware LED. Comparatively, the AMA's PPPs and hardware interventions implemented by the SODA are similar since they were aimed at infrastructure provision. In addition, both the AMA and SODA leveraged on the available lands to woo investors to their respective localities. The AMA for instance, offered lands as its equity to the PPPs (Table 3) and the SODA also offered land and enabling environment for companies such as the Golden Exotics Company Ltd (GEL) and Sheenfeel Company Ghana Ltd.

Table 3. Summary of AMA PPP Projects

\begin{tabular}{|c|c|c|c|c|c|}
\hline Item & Project & $\begin{array}{l}\text { Transaction } \\
\text { Advisor }\end{array}$ & $\begin{array}{l}\text { Estimated } \\
\text { Land Size } \\
\text { in acres }\end{array}$ & $\begin{array}{l}\text { Estimated } \\
\text { Value in US\$ }\end{array}$ & $\begin{array}{l}\text { Contractor } \\
\text { after } \\
\text { Request for } \\
\text { Proposal } \\
\text { (RFP) } \\
\end{array}$ \\
\hline 1 & Mallam Market & $\begin{array}{l}\text { CPCS } \\
\text { International }\end{array}$ & 5.84 & $17,680,000.00$ & \\
\hline 2 & $\begin{array}{l}\text { Makola/31 } 11^{\text {st }} \text { December } \\
\text { Market }\end{array}$ & $\begin{array}{l}\text { Deloitte and } \\
\text { Touché }\end{array}$ & 7.5 & $29,046,600.00$ & $\begin{array}{l}\text { Excellent and } \\
\text { Wilson }\end{array}$ \\
\hline 3 & Tuesday Market & $\begin{array}{l}\text { Kwame } \\
\text { Ansah and } \\
\text { Associates }\end{array}$ & 4.08 & $24,345,862.00$ & $\begin{array}{l}\text { Pro Design } \\
\text { Ltd }\end{array}$ \\
\hline 4 & Salaga Market & $\begin{array}{l}\text { Kwame } \\
\text { Ansah and } \\
\text { Associates }\end{array}$ & 1.27 & $4,055,946.00$ & \\
\hline 5 & London Market & $\begin{array}{l}\text { Kwame } \\
\text { Ansah and } \\
\text { Associates }\end{array}$ & 0.7 & $2,766,986.00$ & \\
\hline 6 & $\begin{array}{l}\text { City Corner Residential } \\
\text { Housing }\end{array}$ & C-Nergy & 7.27 & $307,436,607.00$ & $\begin{array}{l}\text { Excellent, } \\
\text { Buddos and } \\
\text { Sino Ltd }\end{array}$ \\
\hline 7 & $\begin{array}{l}\text { Convention/Community } \\
\text { Center }\end{array}$ & C-Nergy & 3.77 & $156,558,513.00$ & \\
\hline 8 & Mallam Atta Market & $\begin{array}{l}\text { Ernst and } \\
\text { Young, } \\
\text { Ghana }\end{array}$ & 12.08 & $89,000,000.00$ & \\
\hline 9 & Katamanto Market & $\begin{array}{l}\text { Shawbell } \\
\text { Consulting }\end{array}$ & 10.71 & $25,200,000.00$ & \\
\hline 10 & PWD and Kwasiadwaso & PKF & 11.4 & $50,700,000.00$ & $\begin{array}{l}\text { Consiki with } \\
\text { EBID }\end{array}$ \\
\hline 11 & Accra City Car Parks & - & 0.4 & $5,500,000$ & $\begin{array}{l}\text { Seth Adjei } \\
\text { and } \\
\text { Consortium }\end{array}$ \\
\hline
\end{tabular}

Source: Public Investment Division of MOFEP and Fieldwork, January, 2018

The business development programmes by the AMA, software LED by the SODA and the non-traditional LED interventions by the KeMA are also similar because the end results were to develop the capacities of the indigenes and their business establishments through resourcing them to be capable both financially and skills wise. In addition, the three Metropolitan, Municipal and District Assemblies implemented LED programmes aimed at 
value addition. For instance, the capacity development programmes for beads making, bag weaving with straw and raffia (ketsi) among others at KeMA enabled the indigenes to utilize the natural resources by way of value addition and the capacity development programmes for mango farmers in Dodowa and Agomeda on one hand and same for rice farmers in Asutauare also ensured that the beneficiaries got the maximum yield from their farming activities. Furthermore, both the AMA and SODA sought to take advantage of national and international markets. This was done in the SODA by the Millennium Development Authority (MiDA) through the establishment of business linkages between the mango farmers and the business world whilst that of the AMA was done by incorporating quality control measures, advertising and marketing into the product and training programmes. The KeMA's capacity development programme had no direct intention of taking advantage of the marketing opportunities; however, it had a separate initiative of creating marketing opportunities through attending and exhibiting LED products at trade fairs in the country.

Analysis of the LED interventions also showed some disparities. For instance, whilst the AMA's LED programmes were focused on PPPs and the indigenes taken advantage of both national and international markets, the KeMA was concerned with indigenous capacity development, value addition to the natural resources and the provision of marketing opportunities for the products of the LED beneficiaries locally and nationally. With respect to infrastructure provision, while the AMA used PPP arrangements, the Golden Exotics Limited which is a company in SODA championed the infrastructure provision as part of its corporate social responsibility (CSR).

Even though the KeMA and SODA used their available natural resources for the implementation of LED initiatives, there were some variations. In the KeMA, apart from the bag weaving which made use of the natural resource endowment of the municipality, the other initiatives such as batik, tie and dye, hair dressing among others did not use raw materials from the locality. In contrast to the KeMA, the SODA took advantage of the water-logged and fertile nature of the land for rice production to undertake large scale rice production and also leveraged on the 22 kilometer stretch of the Volta River that washes the north-eastern portions of the district to promote fish (tilapia) farming in the district.

In terms of financial accessibility as a LED intervention, the partners of the AMA in the Accra City Car Parks Ltd namely; Merchant Bank (now Universal Merchant Bank Ghana Ltd (UMB)), First Africa Group, Labour Enterprise Trust, ELGA Ghana, OMNIA, and Seth Adjei and Consortium provided a total of US\$ 5.5 million for the project in 1997 (Table 4) and the Social Investment Fund (SIF) funded the business development services programmes (Table 5) whilst the KeMA and SODA relied on the use of Medium and Small Loan Company (MASLOC) (a government initiative to boost local entrepreneurship) and financial institutions (Dangbe and Shai Rural Banks) respectively.

Table 4. Shareholding structure for financing the Accra City Car Parks Ltd in the AMA

\begin{tabular}{l|c|c}
\hline Name of Actor & Amount in US\$ & Equity in Percentage \\
\hline AMA & 550,000 & $10 \%$ \\
\hline UMB & 594,550 & $10.81 \%$ \\
\hline First African Group & 2,051500 & $37.3 \%$ \\
\hline
\end{tabular}




\begin{tabular}{l|c|c}
\hline Labour Enterprise Trust & $1,217,150$ & $22.13 \%$ \\
\hline ELGA Ghana & 748,000 & $13.6 \%$ \\
\hline OMNIA & 128.150 & $2.33 \%$ \\
\hline Seth Adjei and Consortium & 210,650 & $3.83 \%$ \\
\hline Total & $\mathbf{5 , 5 0 0 , 0 0 0}$ & $\mathbf{1 0 0 \%}$ \\
\hline
\end{tabular}

Source: Accra City Car Parks Ltd, February, 2018

Table 5. Cost of implementing capacity development programme in the AMA in 2012

\begin{tabular}{l|l|l}
\hline No & Name/Type of Intervention & Cost in US Dollars \\
\hline 1 & Technological improvement for SSEs Development & $19,798.57$ \\
\hline 2 & Enhancing local and national for SSEs & $15,782.50$ \\
\hline 3 & Creating enabling environment and dialogue & $17,245.53$ \\
\hline 4 & Promoting SSEs development & $14,680.98$ \\
\hline & Total & $67,507.58$ \\
\hline
\end{tabular}

Source: Social Investment Fund, March, 2018

The difference between the AMA on one hand and KeMA and SODA on the other hand is due to a number of reasons. First, the AMA is an urban Assembly hence its ability to attract funding from the Social Investment Fund for its Urban Poverty Reduction Project (UPRP) whilst the KeMA and SODA are rural-coastal and rural-forest Assemblies respectively. Second, the AMA is the economic hub of Ghana hosting a total of 17 commercial, developmental and merchant banks with 107 branches (www.ghanadistricts.com) whilst the KeMA has one each of rural and commercial banks and the SODA two rural banks and one commercial bank. The KeMA used the MASLOC because of the unwillingness of the financial institutions (the Anlo Rural Bank) to extend financial credits to the local entrepreneurs as indigenes in the past did not repay loans given to them. The SODA used the Shai and Dangbe Rural Banks because of their willingness to assist in granting the credit facility. Putting together all the three Metropolitan, Municipal and District Assemblies' LED interventions, one could say that whilst the AMA generally pursued contemporary and private sector led LED, the KeMA and the SODA have implemented traditional and locality driven LED interventions.

In terms of the indigenes who benefitted from the various LED interventions, 132 respondents representing $74.2 \%$ from the AMA indicated that they benefitted from capacity development programmes whilst 46 respondents representing $25.8 \%$ indicated not applicable because they had no direct employment through the LED initiatives. In KeMA, 177 of the respondents representing $99.4 \%$ indicated capacity development as the LED initiative they benefitted from whilst one respondent representing $0.6 \%$ indicated the creation of marketing opportunities as the LED initiative benefit. One hundred and seventy six (176) respondents representing $99.4 \%$ indicated capacity development programme and provision of agricultural inputs as the LED initiative they benefitted from in SODA whilst one respondent representing $0.6 \%$ also benefitted from capacity development programme, agricultural inputs and marketing opportunities (Table 6). 
Table 6. LED initiatives in the AMA, KeMA and SODA

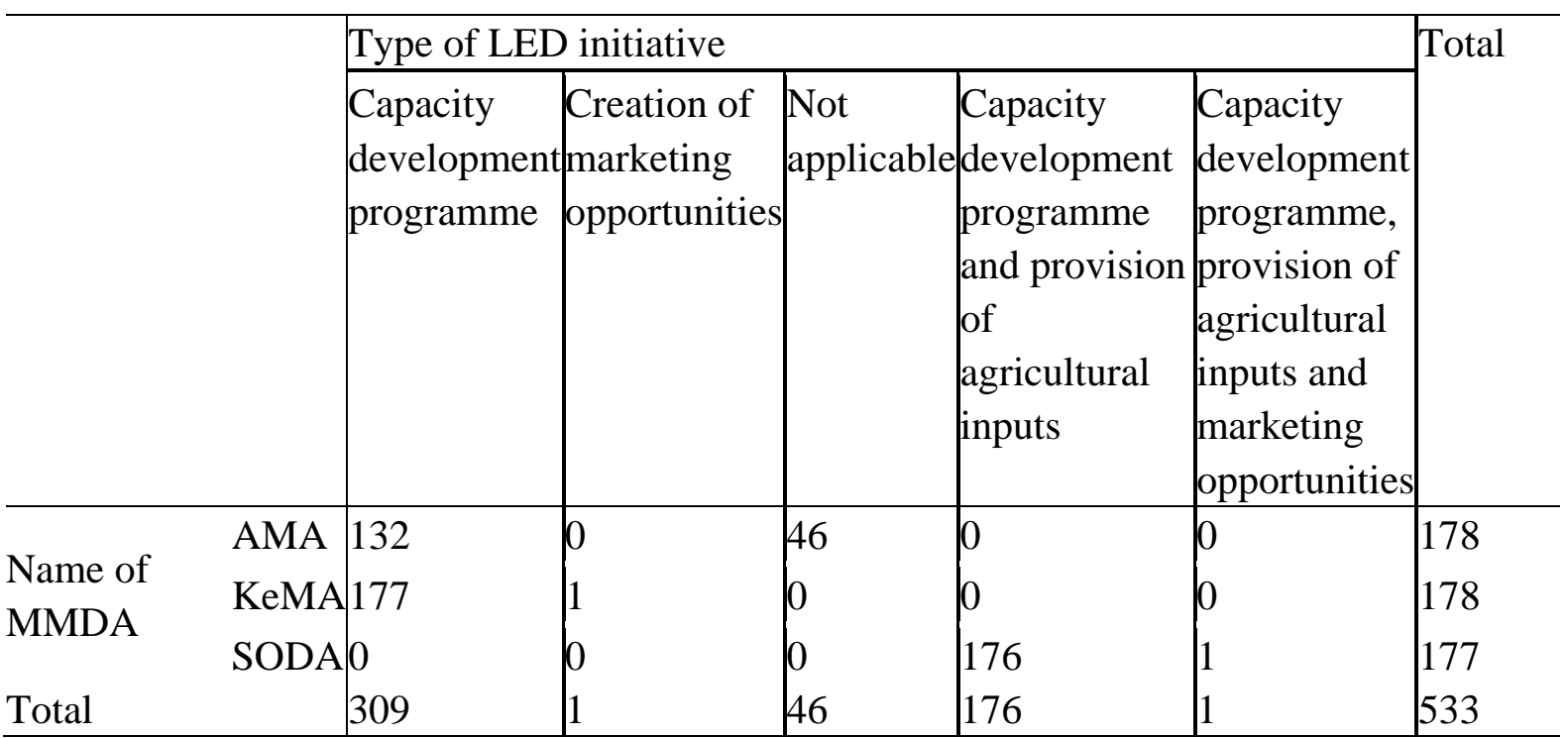

Source: Fieldwork, January, 2018

Figure 1 below indicates a summary of the MMDAs and their various LED initiatives.

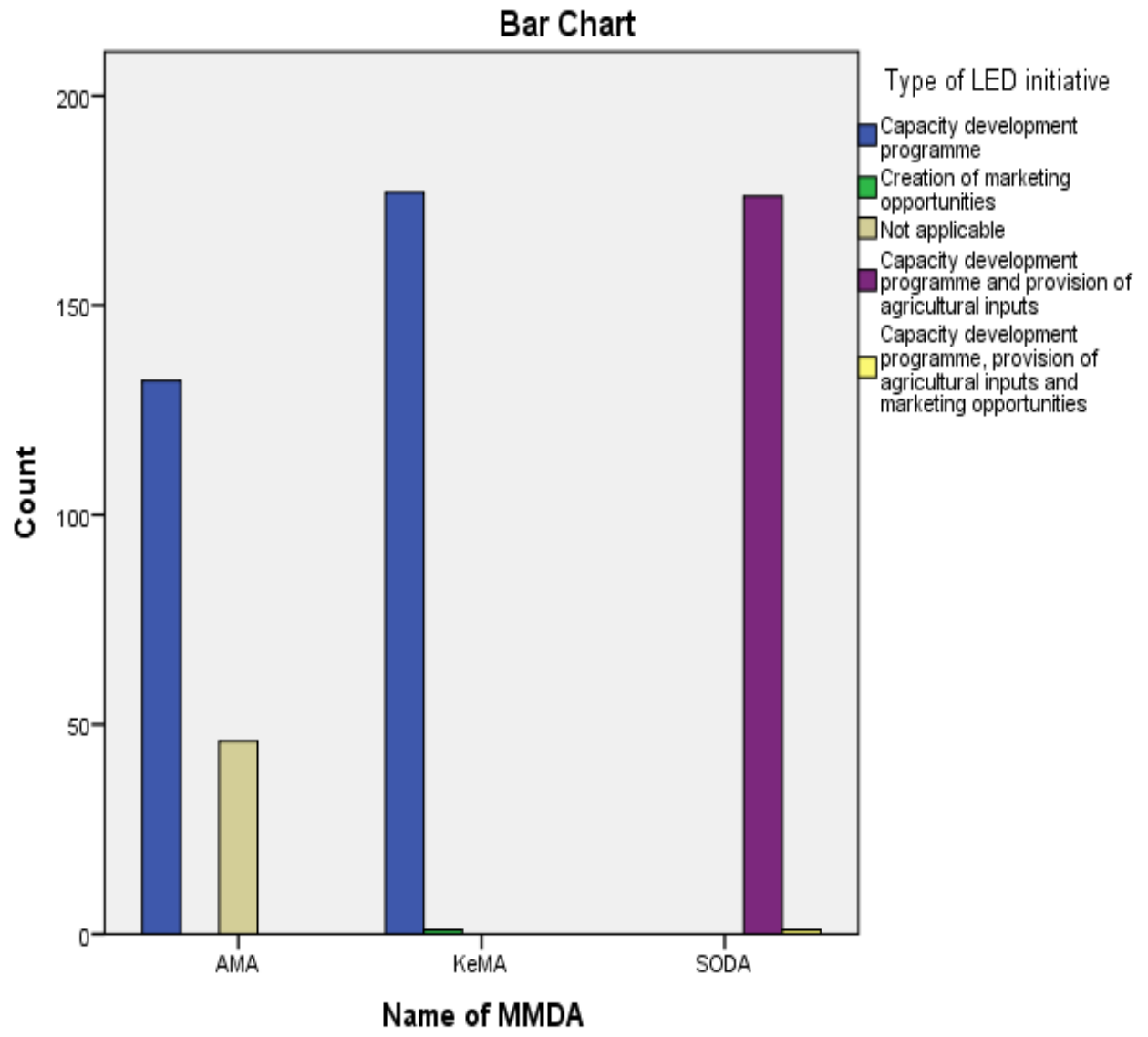

Figure 1. MMDAs and LED Initiatives

Source: Fieldwork, January, 2018 


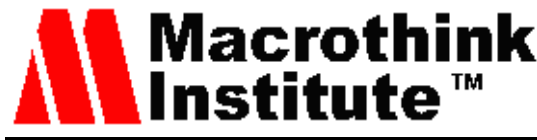

Journal of Public Administration and Governance

ISSN 2161-7104

2018, Vol. 8, No. 4

From Figure 1, though the indigenes benefitted from LED interventions, it could be distilled that whilst 132 respondents from the AMA benefited directly from the capacity development programmes, another 46 are end result (employment opportunity creation) beneficiaries. The end employment opportunities were created by the 132 respondents who benefitted from the capacity development programmes. In KeMA, 177 and one respondents benefitted from the capacity development programme and creation of marketing opportunities respectively. Whilst in SODA, 176 of the respondents benefitted from a combination of capacity development programmes and provision of agricultural inputs and one respondent also benefitting from a blend of capacity development programmes, provision of agricultural inputs and marketing opportunities. In short, one can say that all the respondents in the KeMA and SODA benefitted from LED interventions whilst in the AMA, those who gave not applicable are end result beneficiaries of LED.

\subsection{Challenges to LED Implementation in AMA, KeMA and SODA}

The challenges faced by the three Metropolitan, Municipal and District Assemblies in the implementation of LED can be grouped into: inadequate finance, lack of institutional capacity, policy inconsistency, lack of both political and leadership commitment and support to implement Metropolitan, Municipal and District Assembly bye-laws, non-availability of land, and the politicization of LED (Table 7and Figure 2).

First, the three assemblies had challenges with financing their LED activities. This challenge for instance, compelled the AMA to opt for PPPs as the driver of LED. In the case of the KeMA, the challenge was in getting budgetary allocation for the implementation of LED programmes and start-up capital for LED beneficiaries. SODA's financial challenge also hindered the LED beneficiaries from buying inputs and chemicals for their farms. The financial challenge equally impacted the activities of the LED beneficiaries. For instance, 32 (18\%), $24(13.4 \%)$ and $21(12 \%)$ of the respondents of the AMA, KeMA and SODA respectively indicated finance as a challenge they faced (Table 7)

Second is, lack of knowledge in modern trends and equipment. This challenge was peculiar to only KeMA and SODA. In the KeMA, the beneficiaries had foundational capacity development programmes hence their products were unable to compete externally and they also lacked modern equipment in hair dressing, batik, tie and dye among others. On the part of SODA, the farmers lacked modern equipment for land preparation and harvesting. In cases where the equipment were available, they were inadequate. For instance, the Ghana Rice Inter-professional Body (GRIB) had one transplanter, three power tillers and one thresher which served 2,480 registered rice farmers.

Third is, challenge over land, which was pronounced in the AMA. The study found that the AMA did not have title to the lands that it earmarked for the ten PPPs. This culminated into $72(40.4 \%)$ of the LED beneficiary respondents in the AMA having challenge with land to carry out their business operations. The KeMA on the other hand had little challenge with land compared to the AMA. Fifteen $(8.4 \%)$ beneficiary respondents in the KeMA intimated that they had challenge with getting a place to put their containers. The SODA respondents did not have any challenge with land. This was due to the LED intervention of easy business 
permit and the Kpong Irrigation Scheme (KIS) irrigation lands that the rice farmers were using.

Lack of access to market, problem of getting permit to operate business had a cumulative percentage of $23(4.3 \%)$ respondents across the three local government units. However, $0.3 \%$, $76 \%$ and $86 \%$ representing six (6), 135 and 152 respondents of the AMA, KeMA and SODA respectively intimated that a combination of challenges such as finance, land, lack of modern knowledge, equipment and technology hindered them in their operations as LED beneficiaries.

Table 7. The challenges faced by LED beneficiaries in the AMA, KeMA and SODA

\begin{tabular}{|c|c|c|c|c|c|c|c|c|c|c|c|}
\hline & & \multicolumn{9}{|c|}{ What are the challenges faced after the training programme } & \multirow[b]{2}{*}{ Total } \\
\hline & & Finance & $\begin{array}{l}\text { No marketing } \\
\text { opportunities }\end{array}$ & $\begin{array}{l}\text { Difficulty in } \\
\text { getting a } \\
\text { place to set } \\
\text { up }\end{array}$ & $\begin{array}{c}\text { Difficulty in } \\
\text { getting } \\
\text { permit }\end{array}$ & $\begin{array}{c}\text { Lacks latest skills } \\
\text { in knowledge } \\
\text { acquired }\end{array}$ & $\begin{array}{c}\text { Lack of modern } \\
\text { equipment in } \\
\text { trade learnt }\end{array}$ & $\begin{array}{c}\text { Combination } \\
\text { of the above } \\
\text { challenges }\end{array}$ & $\begin{array}{c}\text { No } \\
\text { response }\end{array}$ & $\begin{array}{c}\text { Not } \\
\text { applicable }\end{array}$ & \\
\hline \multirow{4}{*}{$\begin{array}{l}\text { Name of } \\
\text { MMDA }\end{array}$} & AMA & 32 & 11 & 72 & 10 & 0 & 0 & 6 & 1 & 46 & 178 \\
\hline & KeMA & 24 & 0 & 15 & 2 & 1 & 1 & 135 & 0 & 0 & 178 \\
\hline & SODA & 21 & 0 & 0 & 0 & 0 & 4 & 152 & 0 & 0 & 177 \\
\hline & & 77 & 11 & 87 & 12 & 1 & 5 & 293 & 1 & 46 & 533 \\
\hline
\end{tabular}

Source: Fieldwork, January, 2018

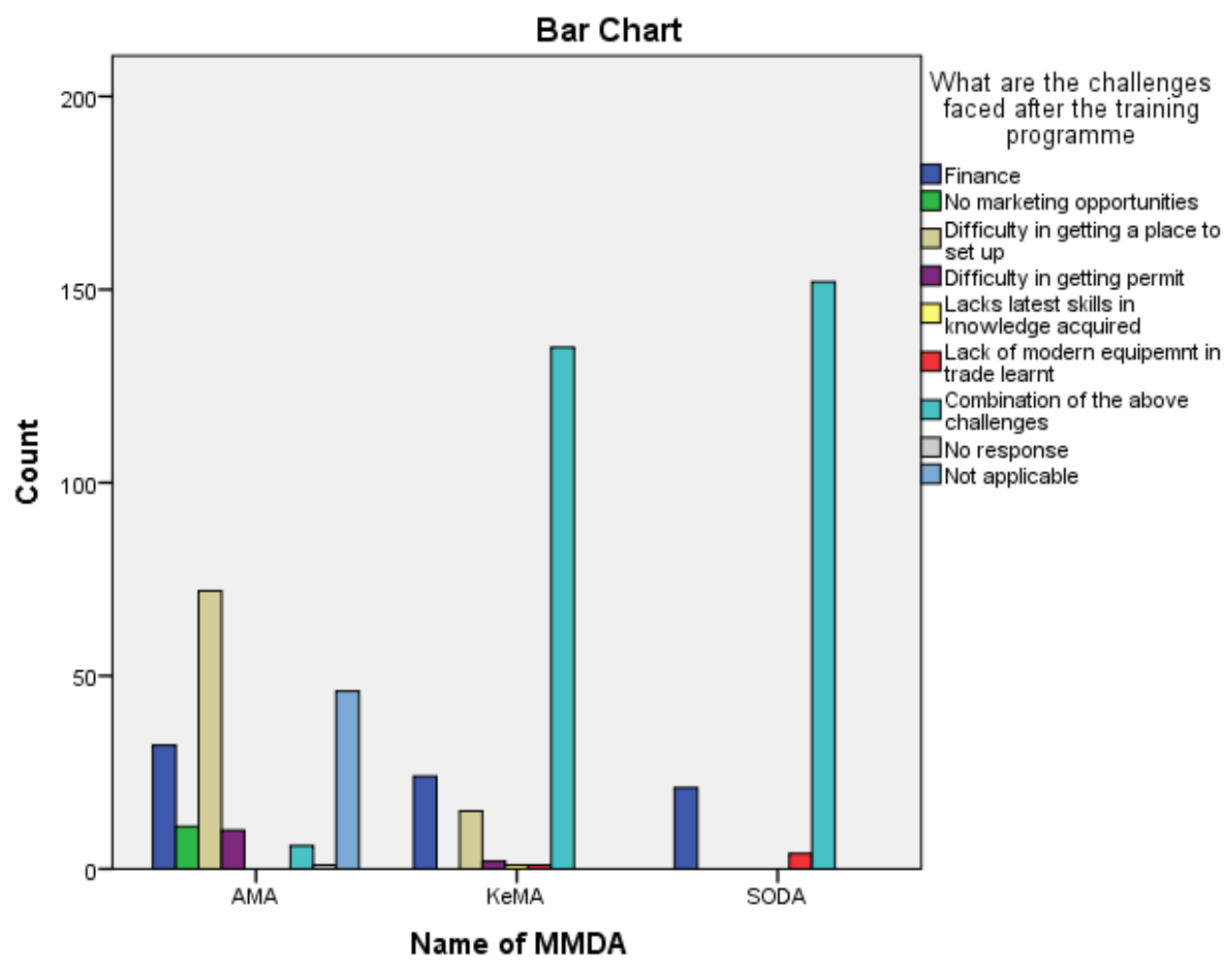

Figure 2. Challenges faced by LED beneficiaries in the AMA, KeMA and SODA 
Source: Fieldwork, January, 2018

Fourth is, lack of capacity. The three assemblies did not have the requisite human resource and institutional capacity for the implementation of LED. In the three assemblies, there were no designated LED officers. The planning officers were responsible for LED in the AMA and SODA whilst the Municipal Coordinator (MC) of the Business Advisory Centre (BAC) was in charge of LED in KeMA. As a result, LED did not receive the needed attention as a priority policy intervention to improve the quality of life in the Metropolitan, Municipal and District Assemblies.

Fifth is policy inconsistency which was unique to the AMA. In the AMA's city car park project, there was a 550 car park capacity, however, the AMA also implemented the "AMA on-street-parking policy" which allowed motorists to park on the street at a fee which went directly to the AMA. Related to this was the activities of some of the AMA guards who extorted money from motorists to park at unauthorised places. These undermined the operations and sustainability of the Accra City Car Park project.

Sixth is the politicization of LED initiatives. In the AMA, for instance, the politicization took the form of political patronage where the political party in power always sought to reward its loyalists by awarding them with PPP contracts. Accordingly, whenever there was a regime change, the entire process was reversed or ongoing projects were halted- policy discontinuity. In the case of KeMA, the politicization was evident during election periods. It is during election periods that politicians inject money into empowerment activities that will garner votes for them. Attempts by the Municipal Coordinator of the Business Advisory Centre to depoliticize LED resulted in participants in Afiadenyigba boycotting a training programme in kente weaving. In the SODA, the change in assembly membership for the Agomeda electoral area, District Chief Executive (DCE) and District Coordinating Director (DCD) positions resulted in the Agomeda and Dodowa mango farmers respectively failing to participate in the LED process.

\section{Recommendations}

1. Harmonization of all poverty reduction related policies of the current NPP government such as the "Planting for Food and Jobs", "One District One factory (1D1F)", and the LED so that resources can be channeled to make implementation coherent and effective instead of the current situation where scarce resources are dissipated among competing policies such as the "Planting for Food and Jobs" and "1D1F". The dissipation of scarce resources starves the policies and the implementing institutions of the needed resources.

2. The NPP government's flagship programme should be extended to the Shai-Osudoku District Assembly for the establishment of mango and rice processing factories so that value can be added to these products before getting to the market. In the KeMA, an anchovy processing factory should also be established to kick start a LED intervention because of its comparative advantage.

3. The National LED policy and the Operational Manual should be launched and its implementation effected immediately to make it mandatory for all local government units to 
implement LED interventions. To whip up the commitment level of assemblies to the implementation of LED interventions, incentives such as annual awards and locality marketing should be instituted as some benefits to Metropolitan, Municipal and District Assemblies for championing LED implementation.

4. There should be a central government fund specifically designated for the financing of LED activities in all the assemblies in the country. In this connection a certain percentage of the District Assemblies Common Fund (DACF) should be earmarked for the implementation of LED policies in the localities instead of the current practice where local authorities have the luxury of determining whether to spend a portion of the District Assembly Common Fund on LED or not.

5. The implementation of change management strategies. Change management in this context refers to deliberate interventions aimed at modifying the existing values, norms, the organisational structure and the behaviour of the human resource to reorient them towards the implementation of LED interventions. Strategies such as training, team building, and empowerment among others could be implemented to develop the capacity of the staff of the LED unit and other officials involved in LED implementation. The norms, values, goals and the structure of institutions involved in LED implementation should be aligned to the vision and goal of the LED policy. This will make the institutions and the human resource to be proactive in the implementation of LED.

6. LED intervention implementation should not be tied to the tenure of office of the Metropolitan, Municipal and District Chief Executives (MMDCEs) and District Coordinating Directors (DCDs) at the assemblies; rather, it should be continued even when there is a change in leadership at the assemblies. Related to this recommendation is that the central government should desist from interfering in recruitment through transfers at the local governance level. This does not auger well for the continuation of LED policies.

7. Incentives should be made available with strict legal and institutional regimes in the Metropolitan, Municipal and District Assemblies for LED promotion. These incentives should be created at where they are needed to avoid "building cathedrals in deserts". The existence of incentive schemes at the assemblies have the potential of attracting investments to the areas thereby creating employment opportunities, income generation and ultimately reducing poverty.

8. Politicians at all levels should desist from the over-politicization of LED interventions. They should rather make these resources available to the local authorities to facilitate the implementation of LED.

9. Central government's involvement in the implementation of LED should not be driven purely by the electoral fortunes it stands to gain, but rather should fall within the general development plan of the nation and the local government units in particular.

\section{Conclusion}

The article concludes that the three assemblies though pursued LED strategies that seem to be 
different, a careful examination revealed some similarities. The three MMDAs faced similar challenges in the LED implementation process. These challenges hindered the effective implementation of the initiatives thereby reducing the number of participants in each of the assemblies.

\section{References}

Akudugu, J. A. (2013). Organising and implementing local economic development initiatives at the district level in Ghana.

Amoako-Tuffour, J. (2008). The evolution of Poverty in Ghana: 1960-2000. Poverty Reduction Strategies in Action: Perspectives and Lessons from Ghana, 17.

Ayee, J. R. (2007). Ghana at 50: government, politics, and development. Dept. of Political Science, University of Ghana.

Čapkova, S. (2005). Local Government and Economic Development, in Čapkova S (ed.), Local Government and Public Service Reform Initiative, Budapest and the Department of International Development Publication.

Edoun, E. I., \& Jahed, M. (2009). The merits of decentralisation and local economic development in South Africa. Pretoria: Global Action for Africa's Development.

Enzama, W. (2008). Quest for economic development in agrarian localities. ISS Working Paper Series/General Series, 452, 1-46.

Ghana, Republic of (2013). National Local Economic Development (LED) Policy, Accra: Ministry of Local Government and Rural Development.

Ghana, Republic of (2014). Operational Manual on LED for District Assemblies in Ghana, Accra: Ministry of Local Government and Rural Development.

Helmsing, A. J. H. (2001). Partnerships, Meso-institutions and Learning: New Local and Regional Economic Development Initiatives in Latin America, The Hague: Institute of Social Studies.

Helmsing, A. J. H. (2003). Local Economic Development: New Generations of Actors, Policies and Instruments for Africa, Public Administration and Development, 67 - 76.

Khumalo, P. (2015). Decentralisation and Local Economic Development in Four Southern Africa Countries, Journal of Social Science, 45(1), 22-30.

Masuku, M. M., Jili, N. N., \& Selepe, B. M. (2014). The Implementation of Local Economic Development Initiatives towards Poverty Alleviation in Big 5 False Bay Local Municipality, African Journal of Hospitality, Tourism and Leisure, 5(4), 1-11.

Mensah, J. K., Bawole, J. N., \& Ahenkan, A. (2013). Local economic development initiatives in Ghana: The challenges and the way forward. Journal of Public Administration and Governance, 3(2), 142-160. 
Mensah, J. K., Domfeh, K. A., Ahenkan, A., \& Bawole, J. N. (2013). Policy and institutional perspectives on local economic development in Africa: The Ghanaian perspective. Journal of African Studies and Development, 5(7), 163-170. https://doi.org/10.5296/jpag.v3i2.3781

Nel, E. (2001). Local economic development: A review and assessment of its current status in South Africa. Urban studies, 38(7), 1003-1024. https://doi.org/10.1080/00420980120051611

Nyawo, J., \& Mubangizi, B. C. (2015). Art and craft in local economic development: Tourism possibilities in Mtubatuba Local Municipality. African Journal of hospitality, Tourism and leisure, 4(2), 1-15.

Oduro-Ofori, E. (2016). Decentralisation and Local Economic Development Promotion at the District Level in Ghana. In Decentralisation and Regional Development (pp. 15-36). Springer, Cham. https://doi.org/10.1007/978-3-319-29367-7_2

Ofei-Aboagye, E. O. (2009). Economic decentralization and local development: Concepts and issues. Journal of Local Government Studies, 1(1), 1-28.

Pieterse, E. (2006). A Framework to Link Local Economic Development to Anti-Poverty Strategies, accessed at http://www.dplg.gov.za, retrieved on $17^{\text {th }}$ March, 2017. www.ghanadistricts.com, retrieved on $23^{\text {rd }}$ October, 2017.

Ramukumba, T. (2012). The local economic development in the Eden District municipality, Western Cape Province, South Africa: A case study of emerging entrepreneurs in tourism industry. American Journal of Tourism Research, 1(1), 9-15.

Rodriguez-Pose, A., \& Tijmstra, S. (2005). Local Economic Development as an Alternative Approach to Economic Development in Sub Saharan Africa, A Report for the World Bank, Washington DC: The World Bank, 1-20.

Rogerson, C. M., \& Rogerson, J. M. (2010). Local economic development in Africa: Global context and research directions. Development Southern Africa, 27(4), 465-480. https://doi.org/10.1080/0376835X.2010.508577

Tsikata, K. (2007). Challenges of economic growth in a liberal economy, in Boafo-Arthur K, (ed.), Ghana: One Decade of the Liberal State, London: Zed Books.

UN-HABITAT (2005). Promoting LED Strategic Planning: Vol. 1 Quick Guide, Nairobi: UN-HABITAT and Eco Plan International Inc.

World Bank (1989). Sub-Saharan Africa: From Crisis to Sustainable Growth, Long Term Perspective Study, Washington DC: The World Bank.

World Bank (2003). Local Economic Development a Primer: Developing and Implementing Local Economic Development Strategies and Action Plans, Washington DC: World Bank.

Wunsch JS (2014). Decentralisation: Theoretical, Conceptual and Analytical Issues, in Dickovick JT and Wunsch JS (eds.), Decentralisation in Africa: The Paradox of State Strength, London: Lynne Rienner. 


\section{Macrothink}

Journal of Public Administration and Governance ISSN 2161-7104 2018, Vol. 8, No. 4

Yatta, F. (2015). Local Economic Development in Africa: Implementation, Constraints and Prospects, Dialogue and capacity building of local and regional authorities in EU partner countries in the fields of development and local governance, Kampala: PLATFORMA.

\section{Copyright Disclaimer}

Copyright for this article is retained by the author(s), with first publication rights granted to the journal.

This is an open-access article distributed under the terms and conditions of the Creative Commons Attribution license (http://creativecommons.org/licenses/by/4.0/). 